\title{
2.3. КОНЦЕПЦИЯ УЧЕТА И ОТЧЕТНОСТИ ДВИЖЕНИЯ КАПИТАЛА В СОЦИАЛЬНО-ЭКОНОМИЧЕСКОМ РАЗВИТИИ: ИНСТИТУЦИОНАЛЬНЫЙ ПОДХОД
}

Энус Шакер Мухаммад, аспирант, кафедра «Бухгалтерский учет и налогообложение»

\author{
Российский экономический университет им. Г.В. Плеханова, г. Москва
}

В условиях устойчивого развития актуальными становятся исследования эволюции и современных концепций учета и движения капитала. В онтологии современной концепции капитала закрепляется его характеристика, раскрывающая капитал как накопленный путем сбережений запас экономических благ в форме денежных средств и реальных капитальных товаров. Собственник капитала всегда ожидает будущего дохода от вовлеченного капитала в экономические системы в условиях альтернативных оценок, формирующихся под фракторами возможностей и рисков.

\section{Литература}

1. Ковалев В.В. Финансовый менеджмент: теория и практика [Текст] / В.В. Ковалев. - 3-е изд., перераб. и доп. - М. : Проспект, 2017. - 1104 с.

2. Леотей Е. Общие руководящие начала счетоведения [Текст] : Е. Леотей, А. Гильбо ; пер. Н.В. Богородского ; под ред. А.П. Рудановского. - М. : МАКИЗ, 1924. -403 с.

3. Львова Д.А. Истоки теории бухгалтерского учета общественного сектора экономики [Текст] / Д.А. Львова. - СПб. : Издво СПб. ун-та, 2014. - 160 с.

4. Рудановский А.П. Теория балансового учета. Оценка, как цель балансового учета, счетное исчисление [Текст] / А.П. Рудановский. - М. : МАКИЗ, 1928.

5. Соколов Я.В. Основы теории бухгалтерского учета [Текст] / Я.В. Соколов. - М. : Финансы и статистика, 2003. - 493 с.

\section{Ключевые слова}

Концепция; концепция капитала; учет и отчетность движения капитала; социально-экономическое развитие; институциональный подход.

\section{Энус Шакер Мухаммад}

\section{РЕЦЕНЗИЯ}

Концепция капитала в теории бухгалтерского учета с позиции институционального подхода позволяет выявить направления формирования внутренней информационной составляющей для принятия оперативных, тактических и стратегических решений. Именно поэтому важность капитала в теории бухгалтерского учета состоит в возможности провести построение институциональной модели в условиях стратегического развития бизнеса, что предполагает функционирование и адаптацию адекватных систем учета, что отражают стоимость и ценность капитала.

Автор совершенно справедливо утверждает, что подход к исследованию экономической науки развивается на платформе методологического и аналитического инструментария, совершенствование которого осуществляется за счет междисциплинарных связей, в том числе бухгалтерского учета. Следует отметить, что, аккумулируя существенный поток информации о научных институтах, смежных с теорией бухгалтерского учета, важно применять институциональный подход к разрабатываемым концептуальным решениям.

В статье автор синтезирует различные понятия и представляет современную концепцию учета и движения капитала. В авторской концепции даны понятие, цели, задачи, принципы, структурные элементы, система, что существенно раскрывает онтологию капитала и процессы его генезиса и движения.

Автору становится очевидным, в чем его следует поддержать, что методы оценки играют ключевую роль в формировании и движении экономической категории «капитал», в дальнейшем анализе его структуры.

Все вышеизложенное дает основание утверждать, что статья содержит научную новизну, построенную на теоретическом анализе и синтезе; содержание раскрывает поставленную тему. Статья может быть рекомендована к публикации.

Шохнех А.В., д.э.н., профрессор, директор Института технологии, экономики и сервиса ФГБОУ ВО «Волгоградский государственный социально-педагогический университет», г. Волгоград.

DOI 10.38097/AFA.2020.66.55.005 